\title{
German and Asian Perspectives on Company Law
}

\author{
Law and Policy Perspectives \\ Ed. by Holger Fleischer, Hideki Kanda, Kon Sik Kim and Peter Mülbert
}

[Perspektiven des Gesellschaftsrechts in Deutschland und Asien.]

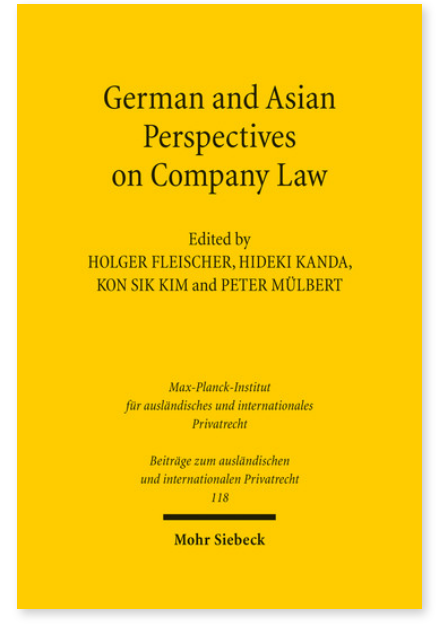

2016. XI, 377 Seiten. BtrIPR 118

ISBN 978-3-16-155138-3

DOI 10.1628/978-3-16-155138-3

eBook PDF $94,00 €$

ISBN 978-3-16-155026-3

Leinen $94,00 €$
Veröffentlicht auf Englisch.

Der vorliegende Band bietet eine umfassende rechtsvergleichende Analyse grundlegender Themen des Gesellschaftsrechts in Deutschland, China, Japan und Südkorea. Untersucht werden Fragen der Verantwortlichkeit von Organmitgliedern und der Kapitalerhaltung ebenso wie die Rolle der Aktionäre in börsennotierten Aktiengesellschaften und die Regulierung des Konzernrechts in diesen vier Rechtssystemen.

Inhaltsübersicht

Introduction

Hideki Kanda: A Brief Guide to Japanese Company Law - Holger Fleischer: A Guide to German Company Law for International Lawyers. Distinctive Features, Particularities, Idiosyncrasies

\section{Directors' Liability}

Kenichi Osugi: Directors' Liability and Enforcement Mechanisms in Japan - Kyung-Hoon Chun: Corporate Opportunity Doctrine as a Basis for Directors' Liability. A New Statutory Experiment in Korea - Jianbo Lou: Ordinary Corporate Conduct Standard vs. Business Judgment Rule. A Review of Case Rulings by Beijing Courts between 2005 and 2014 - Hans Christoph Grigoleit: Directors' Liability and Enforcement Mechanisms from the German Perspective. General Structure and Key Issues

\section{Capital Maintenance}

Gen Goto: Legal Capital in Japan and the Influence of German Law - Andreas Cahn: Capital Maintenance - Ruoying Chen: From Legal Capital to Subscribed Capital. Capital Rule in China and its Economic Background

\section{The Role of Shareholders}

Gerald Spindler: The Role of Shareholders in Public Companies - Kon-Sik Kim/Moon-Hee Choi: Declining Relevance of Lawsuits on the Validity of Shareholder Resolution in Korea. A Comparative Essay - Hiroyuki Kansaku: The Role of Shareholders in Public Companies

IV. Groups of Companies

Junhai Liu: Regulation of Corporate Groups in China - Hyeok-Joon Rho: Corporate Groups in Korea. Reconciliation of Individualism with Collectivism - Eiji Takahashi: Recht und Wirklichkeit der verbundenen Unternehmen in Japan - Katja Langenbucher: Do We Need a Law of Corporate Groups?

Holger Fleischer is Director at the Max Planck Institute for Comparative and International Private Law in Hamburg and Affiliate Professor at the Bucerius Law School, Hamburg.

Hideki Kanda is emeritus Professor at the University of Tokyo and Professor at the Gakushuin University Law School, Japan.

Kon Sik Kim is Professor of Commercial Law at the Seoul National University School of Law, Korea.

Peter Mülbert is Professor of Civil Law, Commercial and Banking Law; Fellow, Gutenberg Research College, and Director of the Center for German and International Law of Financial Services at the University of Mainz.

Jetzt bestellen:

https://mohrsiebeck.com/buch/german-and-asian-perspectives-on-company-law-9783161551383?no_cache=1

order@mohrsiebeck.com

Telefon: +49 (0)7071-923-17

Telefax: +49 (0)7071-51104 